\title{
Loan Repayment Capacity of Cooperative Farmers in Ohaukwu Local Government Area of Ebonyi State, Nigeria
}

\author{
Nwibo, Simon Uguru* and Nwakpu, Cletus ${ }^{1}$ \\ *I Department of Agricultural Economics, Management and Extension Ebonyi State University, Abakaliki
}

\begin{abstract}
Loan repayment is crucial for the long-term sustenance of the credit institutions. But despite the repayment abilities of borrowers, studies showed that the loan repayment capacities of cooperative farmers in Ohaukwu LGA of Ebonyi state seems not to have been empirically documented. Both multistage and purposive sampling techniques were employed to generate data from 80 cooperative farmers using questionnaire administered as interview schedule. Data collected were analysed using both descriptive statistics - percentages and mean, and inferential statistics - principal component factor analysis. Results showed that about $65 \%$ of the cooperative farmers were of producer cooperative society while others belongs to either consumer or thrift and saving cooperative societies. The cooperative farmers repaid about $78 \%$ of the total amount loan obtained. The study identified nature of investment, farm yield, household size, health condition of household member, time of loan disbursement, interest rate of the loan, amount of loan obtained, collateral value, and repayment conditions as the factors influencing cooperative farmers loan repayment, while high interest rate, amount of loan obtained, late disbursement, natural hazard, high illiteracy among co-operator, diversion of fund to nonfarm venture, family size, low farm output/income, and weather vagaries were identified as constraints to loan repayment among cooperative farmers. Based on the findings, the study recommended that financial institutions should address the issue of inadequate credit extended to cooperative farmers by increasing credit supply to them as such will help to improve productivity and income generation.
\end{abstract}

Key Words: Cooperative, farmers, loan, repayment, interest rate

\section{Introduction}

The crucial role of credit in agricultural and economic development cannot be overemphasized. Agricultural credit is one of the pre-requisites for enhancing agricultural output of a country. According to Anigbogu, Onugu, Onyeugbo and Okoli (2014), agricultural credit involves giving out of capital to small scale farmers for the purpose of farming. Adebayo and Adeola (2008) posited that agricultural credit enhances productivity and promotes standards of living by breaking vicious circle of poverty of the small scale farmers. They further reported that credit is not only needed for farming purposes, but also for family consumption expenses, especially during the off season period. Nwachukwu, Alamba and Oko-Isu (2010) further posited that credit is vital for improving the welfare of the poor directly through consumption smoothening that reduces their risk to short term income. It also enhances the production capacity of the poor resource farmers through financial investment in their human and physical capital.

Credit plays significant role in economic transformation and rural development. Agricultural loan is a crucial input required by the small cooperative farmers to establish and expand their farms with objective of increasing agricultural production, enhancing food sufficiency, promoting household and national income and increasing the individual borrower's ability to repay borrowed fund. It enables the poor farmers to tap the financial resources and take advantage of the potentially profitable investment opportunities in their immediate environment (Ojiako and Ogbukwa, 2012). However, its accessibility is essential for improvement in the quality and quantity of farm products, so as to increase farmers' income and reduce rural-urban drift (Kohansal and Mansoori, 2009). Considerable interest have been shown by agricultural economists, planners, policy makers, agribusiness managers, agriculturists and financial institutions on the need to give listening ears to farmers in Nigeria with respect to loan. With these renewed interests in improving the status of the rural resource poor farmers through credit extension, a key issue that has cropped up is the question of loan repayment.

Repayment of borrowed agricultural funds has been one of the numerous challenges of agricultural developments in the developing world (Nwachukwu, et al., 2010). In a bid to reduce loan defaults and enhancing loan repayment performance among Nigeria farmers; formations and memberships of farmers groups have been advocated. A group is termed a collection of individuals among whom a set of interdependent relationship exists (Ofuoku and Urang, 2009). The authors further reiterated that groups are characterized by interactions, shared values and beliefs, common goal structure and ideology. Cooperatives are established by like-minded persons to pursue mutually beneficial economic interest and provide a unique tool for achieving one or more goals in an increasingly competitive global economy. Ojiako and Ogbukwa (2012) opined that 
cooperatives are forms of groups that have been encouraged among farmers as instrument of socioeconomic transformation.

Similarly, ICA (1995) posited that cooperatives are autonomous associations of persons who unite voluntarily to meet their common economic and social needs through a jointly owned and democratically controlled enterprise. Adebayo and Yusuf (2004) also highlighted some of the cooperative goals to include; achieving economy of size, improving bargaining power when dealing with other business, purchasing in bulk to achieve lower prices, and obtaining products and services otherwise not available. Based on the theories of social cohesion and social capital, farmer cooperatives provide smallholder farmers with economies of scale by facilitating cheaper and more efficient access to inputs, improved production techniques and information about markets. According to Akinwumi (2006); Bhuyam (2007), cooperatives are seen as a medium through which services such as farm inputs, farm implements, farm mechanization, agricultural loans, agricultural extension, member education, marketing of members farm produce and other economic activities are rendered to members. Despite these advantages, cooperative farmers have mostly been locked out of the formal financial system. This was mainly due to the absence of bankable collateral, high administrative costs and perceived high risks associated with agricultural and small cooperative farmers (Awoke, 2004).

There is a belief that working under associations and groups, farmers would be empowered to speak and act with one voice and consequently it will become easier for them to process loan through financial institutions. In the same vein, Bibby and Shaw (2005) noted that cooperatives are based on the powerful idea that in togetherness people can achieve goals that none of them can achieve individually. It has been considered as a third force, an alternative and counter availing power to both big business and government (Yamusa and Adefila, 2014). Agricultural cooperatives encourage members to engage in joint civilization of food and cash crops (a society in an advanced state of social development), purchase farm inputs at subsidized prices and create better producer's price for their farm products (Poulton et al., 2006). In view of the low financial capacity and high level of underdevelopment, an individual farmer can't achieve the desires for large-scale production. It's therefore in the farmers' interest that resources are pulled together so as to gain a tremendous collective advantage and thus widening the industrial base of the economy and the management techniques (Epetimehin, 2006).

Many financial institutions in developing countries provide financial services such as saving and credit to aid several smallholder enterprises including farmers. This was in line with the efforts of Millennium development goals which sought to reduce poverty by $50 \%$ by the year 2015 . However, the sustainability and continuity of the financial institutions to increase the volume of credit to stimulate the poverty reduction goal depends on the repayment rates. High repayment rates allow the institutions to lower the interest rates and processing costs and consequently increase patronage of loans. Repayment performance thus serves as a positive signal for increasing the volume of credit availability to various sectors of the economy (Acquah and Addo, 2011).

In Nigeria, the acclaimed importance of credits for agribusiness promotion and development, notwithstanding their acquisition, management and repayment have been burdened with numerous challenges (Oboh and Ekpebu, 2011; Afolabi, 2010), especially for the smallholder farmer (Awoke, 2004). Consequently, Olagunju and Adeyemo (2007) argued concisely that the problem of default in the repayment of agricultural loan is one of the factors that have been strongly against the development of agricultural sector in Nigeria, because it makes less intense the willingness of the financial institutions to increase lending to the sector. Afolabi (2010) identified the major causes of loan default as; loan shortages, delay in the time of delivery, poor supervision, non-profitability of farm enterprises and undue government interventions with the operations of government sponsored programmes. Whatever the cause maybe, one direct consequence of loan default is that it has caused considerable reduction in the loanable funds to greater majority of loan seekers and also requires substantial amount of administrative cost and time to recover the amount in default (Udoh, 2008). Despite the expected roles of the cooperative groups in promoting loan repayment of its members, limited studies tends to investigate the loan repayment competence of cooperative farmers in Nigeria. Awunyo-Vitor (2012) also reported that the question of repayment of loan by farmers is one of the important issues since it affects access to credit by the farmers. Inability of borrowers to repay amount of loans collected is crucial for the long-term sustenance of the credit institutions. As a result, many studies have tried to examine loan repayment performance of many socio-economic groups. Empirical work by Arene (1992) revealed income, farm size, age of farmers, farming experience and level of education of farmers contributed positively to the credit worthiness of farmers. However, considering various studies on repayment potentials of loan borrowers (Adefila, 2012; Ojiako and Ogbukwa, 2012; Ofuoku and Urang, 2009), the loan repayment capacities of cooperative farmers in Ohaukwu LGA of Ebonyi state seems to have not been empirically documented; hence, the study. To address the problem, the study described the socio-economic characteristics of members of the cooperative societies; characterized the various types of cooperative societies in the area with a view of determining the amount of 
loan obtained and repaid; analyzed the factors that influenced the loan repayment capacities of cooperative farmers; and analyzed the constraints to loan repayment by the cooperative society.

\section{Methodology}

The research was carried out in Ohaukwu L.G.A of Ebonyi State. The area is located between latitude $0.62^{\circ} \mathrm{N}$ and longitude $0.85^{\circ} \mathrm{c}$ east of Greenwich meridian. It occupies a land mass of about $5,0689 \mathrm{~km}^{2}$, with total population of 196,337 persons; 103, 489 females and 92,848 males (NPC, 2006). The Local Government is bounded by Ado local government Area of Benue State in the Northern part, by Ezza North L.G.A in the south, Ishielu L.G.A in the south-west, Ezza south on the north-east and Izzi L.G.A on the North west. The area has 3 major clans (town) namely; the Ngbo, Izhia (Ezzangbo), and Effium. The 3 clans constitute the 14 communities which include; Ukwuagba, Ekwashi, Okposi-eshi, Okposi-eheku, Umuogudu-oshia, Umuogudu-akpu, Umuezeaka, Amoffia, Umuebe, Amike, Amaechi, Umuegara, Effium and Ntsulakpa. The people of Ohaukwu L.G.A. live in a scattered homestead because of their desires to own a vast area of land for farming activities. The vegetation is evenly distributed and the soil type is deep, well drained sandy loam soil and some scattered swampy fields with gentle slope topography. The area has plain land with moderate rainfall ranging between $1500-2000 \mathrm{~mm}$ per annum and an average monthly temperature range of $23^{\circ} \mathrm{C}$ to $27^{\circ} \mathrm{C}$. Farming is the primary occupation of about $95 \%$ of the populations (NPC, 2006). The common crops in the area are; yam, cassava, rice, maize, groundnut, cocoyam, melon and vegetable like tomatoes, okra. They also grow permanent crops like mango, cashew, plantain, banana, guava, pineapple. The people predominantly practice mixed cropping system. Some also engage in shifting cultivation, crop rotation and mixed farming. The people also keep farm animals such as chicken, duck, goat, sheep, and cattle. Though there enterprises are practiced in small scale, they all aimed at profit maximization.

A preliminary study was conducted to determine the sixteen cooperative societies that were registered in the area. Meanwhile, from the registered cooperative societies, eight cooperative societies were purposively selected. This was to ensure that only cooperative societies that were still functional in terms of cooperative activities as well as those that have established links with financial institutions for credit acquisition were sampled. In the $2^{\text {nd }}$ stage, from each of the eight cooperative societies that were purposively selected, ten cooperators were randomly selected to give a total of eighty respondents used as sample size for the study.

Primary and secondary data were used for the study. Primary data were collected using structured questionnaire administered as interview schedule on the eighty respondents. The secondary data were collected from the already established records of the Local Government and Bank of Agriculture (BOA). The data generated were subjected to both descriptive and inferential statistics analysis. Descriptive statistics such as frequency, percentage, and means were used to analyze objectives $\mathrm{i}$ and ii, while inferential statistics of Principal Component Factor analysis was used to achieve objectives iii and iv.

\section{Factor analysis}

Factor analysis was used to identify constraints to repayment ability of the cooperative farmers. The interpretation of the Principal Component Factor was based on the identification of the variables that loaded 0.4 and above as applied by Nwibo and Okorie (2013); Ezeh (2013) as being important in naming a factor. The correlation loading is categorized in this order: $0.30=$ minimal, $0.40=$ important, $0.50=$ practically. Therefore, for a variable to be recognized as having significant contribution, it must load more than 0.40 .

\section{Results And Discussion}

This section presents the analysis of data generated from field survey using appropriate analytical tools. The data were presented in line with the specific objectives and discussions were based on the findings.

\section{Socio-economic Characteristics of the Respondents}

The socio-economic characteristics of the respondents analysed include the age, gender, marital status, household size, educational qualification, annual income and marketing experience. Data collected were analyzed and result presented in Table 1.

The result showed that the cooperative farmers in Ohaukwu LGA were mainly male (80.0\%). The finding corroborates that of Vosanka, Alam, Simon and Rikwentishe (2015) who reported that males dominated membership of farmers' co-operative society in Sardauna Local Government Area of Taraba State. Similarly, Anigbogu, Onugu, Onyeugbo and Okoli (2014) reported that $65 \%$ of cooperative farmers in Awka North L.G.A of Anambra State were males.

Age has been identified as being a key to managerial decision making. From the result, it was observed that the mean age of the cooperative farmers was 46 years which indicated that the farmers are still within their active economic productive age that is required to undertake aggressive farming activities which in turn can enhance their capacity to repay acquired agricultural loan. 
Education is an important socio-economic factor that shapes farmers way of life as its influence farmers' awareness, perception, reception and adoption of innovations that can bring about increase in their income. The educational level of the respondents indicated that about $40 \%$ have completed secondary school while $26 \%$ and $20 \%$ have completed primary and tertiary education respectively and $18 \%$ had no-formal education. This implies that majority of the cooperative farmers had formal education as such can read and write. Hence, they can easily adopt innovations and recommended packages in their farming operations which can lead to increase income generation and the propensity to save for loan repayment.

The analysis of household size indicated a mean of 9 persons per household which was viewed to be relatively a large household size. A large household is vital in the provision of free farm labour; and as such helps farmers in cost saving. By this, the cooperative farmers can save cost associated with hired labour, which can be used to finance loan repayment.

Furthermore, the result indicates that $70.0 \%$ of the co-operators cultivated an average farm size of 2 hectares from where they earned an average annual income of two hundred and eighty-one naira ( $\$ 281,000)$ having stayed in cooperative farming for average of 14 years. The result thus, showed that the cooperative farmers have spent a considerable length of time in farming though they hold a small farm size which may have negative effect on the propensity to save and repay loan. This finding thus justified the assertion of Nwibo, Mbam, and Biam (2016) that farmers become expertise with the length of time spent in farming activities. The experience gained can influence their perception and understanding of socio-economic policies and factors affecting their activities.

Table 1: Distribution of the Respondents According to Socio-Economic Characteristics

\begin{tabular}{|c|c|c|c|c|}
\hline Socio-economic Variables & Description of Variables & Frequency $(\mathrm{N}=80)$ & Percentage & $\bar{x}$ \\
\hline \multirow[t]{2}{*}{ Gender } & Male & 64 & 80.0 & \\
\hline & Female & 16 & 20.0 & \\
\hline \multirow[t]{4}{*}{ Age } & $20-30$ & 10 & 12.5 & 46.4 \\
\hline & $31-40$ & 28 & 35.0 & \\
\hline & $41-50$ & 25 & 31.3 & \\
\hline & 51 and above & 17 & 21.2 & \\
\hline \multirow[t]{4}{*}{ Marital Status } & Single & 8 & 10.0 & \\
\hline & Married & 64 & 80.0 & \\
\hline & Divorced & 4 & 5.0 & \\
\hline & Widowed & 4 & 5.0 & \\
\hline \multirow[t]{4}{*}{ Education level } & No formal education & 14 & 17.5 & \\
\hline & Primary & 18 & 22.5 & \\
\hline & Secondary & 32 & 40.0 & \\
\hline & Tertiary & 16 & 20.0 & \\
\hline \multirow[t]{3}{*}{ Household size } & $1-5$ & 16 & 20.0 & 9 \\
\hline & $6-10$ & 40 & 50.0 & \\
\hline & $11-15$ & 24 & 30.0 & \\
\hline \multirow[t]{3}{*}{ Primary occupation } & Farming & 64 & 80.0 & \\
\hline & Civil service & 12 & 15.0 & \\
\hline & Trading & 4 & 5.0 & \\
\hline \multirow[t]{2}{*}{ Farm size } & $1-2$ & 56 & 70 & 2.03 \\
\hline & $3-4$ & 20 & 25.0 & \\
\hline \multirow{4}{*}{$\begin{array}{l}\text { Duration of cooperative } \\
\text { membership }\end{array}$} & $1-4$ & 28 & 35.0 & 6.4 \\
\hline & $5-8$ & 32 & 40.0 & \\
\hline & $9-12$ & 16 & 20.0 & \\
\hline & Above 12 & 4 & 5.0 & \\
\hline \multirow[t]{5}{*}{ Annual Income } & $\leq 100,000$ & 12 & 15.0 & 281,000 \\
\hline & $100,001-200,000$ & 8 & 10.0 & \\
\hline & $200,001-300,000$ & 32 & 40.0 & \\
\hline & $300,001-400,000$ & 24 & 30.0 & \\
\hline & Above 400,000 & 4 & 5.0 & \\
\hline \multirow[t]{4}{*}{ Farming Experience } & $1-5$ & 4 & 5.0 & 14.1 \\
\hline & $6-10$ & 24 & 30.0 & \\
\hline & $11-15$ & 24 & 30.0 & \\
\hline & Above 15 & 28 & 35.0 & \\
\hline
\end{tabular}

Source: Field Survey, 2017

\section{Types of Cooperative Societies in Relation to Amount of Loan Obtained and Repaid}

This section examined the various types of cooperative societies which the cooperative farmers belong to in relation to the amount of loan obtained and repaid. From the analysis as presented in presented in Table 2, it was observed that $65 \%$ of the sampled respondents were members of producer cooperative society while $15 \%$ belonged to marketing cooperative society, $10 \%$ of them were members of thrift and saving cooperative 
society and $5 \%$ of them belonged to processors and self concern cooperative societies respectively. The large proportion of the respondents whose primary occupation was farming explained why majority of the cooperative farmers were members of producers' cooperative society.

Meanwhile, the result of the amount obtained and repaid by the cooperative societies showed that all the cooperative societies repaid more than $50 \%$ of the borrowed loan. But despite the consumer cooperative society and producers cooperative society borrowing the highest amount of loan, the repayment capacities of the cooperative societies was in a reverse order as thrift and savings, consumers, and producers' cooperative societies repaid the highest amount of loan obtained as justified by the percentage amount repaid. However, on the average, all the cooperative societies repaid about $78 \%$ of the total amount obtained. This finding was further justified by the test of hypothesis which showed that at $5 \%$ level of probability the Z-cal value of 79.56 was greater than the critical value of 1.96 which signifies the acceptance of the alternative hypothesis that there was significant difference between the amount of loan obtained and repaid by the cooperative farmers in the study area. In other words, acquisition of loan has led to increase income generation of the cooperative farmers. Meanwhile, the finding tends to refute the popular opinion that farmers usually divert most of the loan provided for farming activities into non-farming ventures, which results to high rate of loan default.

Table 2: Amount of Loan Obtained and Amount Repaid by Members of the Cooperative Societies

\begin{tabular}{|c|c|c|c|c|c|c|}
\hline Type of cooperatives & $\begin{array}{l}\text { Freq. } \\
(\mathrm{N}=80)\end{array}$ & Percentage & $\begin{array}{l}\text { Mean } \\
\text { amount } \\
\text { obtained }(\mathrm{N})\end{array}$ & $\begin{array}{l}\text { Mean } \\
\text { amount } \\
\text { repaid (N) }\end{array}$ & $\begin{array}{l}\text { Mean } \\
\text { Difference } \\
\text { (A) }\end{array}$ & $\begin{array}{l}\% \text { Amount } \\
\text { repaid }\end{array}$ \\
\hline Producers cooperative & 52 & 65 & 188,430 & 145,365 & 43,065 & 77.1 \\
\hline Processors cooperative & 4 & 5 & 150,350 & 100,445 & 49,905 & 66.8 \\
\hline $\begin{array}{l}\text { Thrift \& saving } \\
\text { cooperative }\end{array}$ & 8 & 10 & 62,200 & 53,575 & 8,625 & 86.1 \\
\hline \multicolumn{7}{|c|}{ Test of hypothesis: Z-test Analysis on Amount of Loan Obtained and Amount Repaid } \\
\hline \multirow{2}{*}{\multicolumn{2}{|c|}{$\begin{array}{l}\text { Amount } \\
\text { Amount obtained }\end{array}$}} & & Std D & \multirow{2}{*}{\multicolumn{2}{|c|}{$\begin{array}{l}\text { Z-cal } \\
79.56\end{array}$}} & \multirow{2}{*}{$\begin{array}{l}2-\mathrm{tab} \\
.96\end{array}$} \\
\hline & & & 11200 & & & \\
\hline
\end{tabular}

Source: Field Survey, 2017.

\section{Factors Influencing Loan Repayment Capacities of Cooperative Farmers}

Principal factor analysis was used to determine factors that influenced loan repayment capacities of cooperative farmers in the study area. The interpretation boils down to identifying variables that load high in each component matrix which were used in naming the factors. According to Kaiser's (1958) rule of thumb, variables with a coefficient of 0.40 or more have high loading and may be used in naming a factor. This rule has been generally applied (Nwibo and Okorie 2013; Ezeh, 2013). Hence, only variables with factor loading of 0.40 and that are at $10 \%$ overlapping variance were used in naming the component factors in this analysis. The summary of the analysis is presented in Table 3.

The result showed that there are two (2) major factors that influenced loan repayment capacity of cooperative farmers and these were categorized into intrinsic and extrinsic factors. The identified intrinsic factors include: type of investment, farm yield, household size, and health condition of household member. Similarly, the identified extrinsic factor include: time of loan disbursement, interest rate of the loan, amount of loan obtained, collateral value, and repayment conditions.

From the result, it was obvious that the capacity of cooperative farmer to repay loan is influenced by both farmer inherent factor - intrinsic and non-farmer inherent factor - extrinsic. Although, it is difficult to separate one from the other as they appear to be interwoven and collectively interplay to influence loan repayment capacity of the beneficiary. The repayment capacity of the farm household depends on whether there is enough cash available in the "family pot" to service the loan. Loan repayments are not made from specially earmarked funds, but are simply taken out of the cash reserves of the household. Thus, the lender needs to figure out if there will be sufficient cash inflows to offset all the outflows, including loan repayment. Some of the cash flows may be regular, while others will be irregular. For farmers, most production-related cash flows are irregular or seasonal in nature. Regular income may come from petty trade activities or off-farm employment, although even these may be affected by seasonal variations (FAO, 2010).

According to Ugbomeh, Achoja, Ideh, and Ofuoku (2008), credit repayment ability could be influenced by a myriad of factors such as interest rate, unstable prices of agricultural commodities, and the social relations and responsibilities of the borrower. Many other factors abound including membership of self - help group; a voluntary association of people at the grass roots level to meet the challenges of economic and business activities in the rural cash economy, like cooperative societies which has been described as a user-owned and democratically controlled enterprise in which benefit is received according to use. Such platform has been used by the governments at various levels to improve the productivity of the farmers and also alleviate the poverty 
and sufferings of the rural resource poor famers. Awunyo-Vitor (2012) noted that in developing countries, improvement in productivity through investment in productive ventures, especially in the agricultural sector where majority of the population derive their livelihood is necessary for accelerated economic growth. At low level of income, the accumulation of savings may be difficult. Under such circumstances, access to loans can help poor farmers to undertake investment and increase productivity.

Studies have shown that there are many factors that influence repayment of credit. For instance, Oladeebo et al. (2008) examined how socio-economic factors such as amount of loan repaid, amount of loan collected and spent on agricultural production, annual net farm income, age, farm size cultivated, farming experience with credit use, and level of education influenced loan repayment among small-scale farmers in Ogbomoso agricultural zone of Oyo State, Nigeria. Among them amount of loan obtained by farmers, years of farming experience with credit use and level of education were the major factors that positively and significantly influenced loan repayment.

Table 3: Factors Influencing Loan Repayment Capacity of Cooperative Farmers

\begin{tabular}{|l|l|l|}
\hline \multirow{2}{*}{ Factors } & Factor I & Factor II \\
\cline { 2 - 3 } & Intrinsic & Extrinsic \\
\hline Type of investment & 0.886 & 0.259 \\
\hline Time of loan disbursement & 0.356 & 0.735 \\
\hline Interest rate of the loan & 0.079 & 0.693 \\
\hline Amount of loan obtained & 0.339 & 0.798 \\
\hline Farm yield & 0.750 & 0.220 \\
\hline Collateral value & 0.287 & 0.743 \\
\hline Household size & 0.922 & 0.245 \\
\hline Repayment conditions & 0.060 & 0.703 \\
\hline Health condition of household member & 0.803 & 0.055 \\
\hline
\end{tabular}

Source: Field Data, 2017.

\section{Constraints to Loan Repayment by Cooperative Farmers}

The ability of farmer co-operators to repay borrowed fund in Ohaukwu LGA of Ebonyi State has been hindered by many identified factors. These factors were analysed and grouped into three - institutional, social and productive constraints (Table 4). Each factor was given a nomenclature that best described or characterized the set of variables contained in it. Factor I was critically examined and named institutional constraint due to the variables that loaded high under it. These include: high interest rate, amount of loan obtained, late disbursement, and natural hazard. Factor II was also considered and named social constraint due to the variables which loaded high under it. These include: high illiteracy among cooperator, diversion of fund to non-farm venture, and family size. Finally, factor III was named productive constraints because most variables that loaded high here were related to it. These were: low farm output/income and weather vagaries. Consequently, institutional, social and productive constraints militate against loan repayment by cooperative farmers in Ohaukwu LGA of Ebonyi State. The finding follows that of Abdu, Mohammed and Sambo (2015) who identified the major problems encountered by farmers during loan repayment to include: bureaucratic procedures, which was due to the fact that the bank has to ascertain that the beneficiary is credit worthy which the farmers consider as a delay in releasing the loan. High interest rate, as the rate was higher than the rate of interest charged by the Bank of Agriculture. Inadequacy of the amount given, this can be attributed to failure of the farmers to meet the requirements for the amount applied for or the inadequacy of the loanable funds.

Table 4: Constraints to Loan Repayment by the Cooperative Farmers

\begin{tabular}{|l|l|l|l|}
\hline Constraints & Factor I & Factor II & Factor III \\
\cline { 2 - 4 } & Institutional & Social & Productive \\
\hline High interest rate & 0.599 & 0.051 & 0.060 \\
\hline High illiteracy among co-operators & 0.372 & 0.846 & 0.291 \\
\hline Amount of loan obtained & 0.588 & 0.045 & 0.024 \\
\hline Late disbursement & 0.890 & 0.361 & 0.264 \\
\hline Low farm output/income & 0.058 & 0.205 & 0.765 \\
\hline Diversion of fund to non-farm venture & 0.211 & 0.790 & 0.056 \\
\hline Natural hazard & 0.691 & 0.016 & 0.049 \\
\hline Weather vagaries & 0.382 & 0.034 & 0.654 \\
\hline Family size & 0.055 & 0.651 & 0.031 \\
\hline
\end{tabular}

Source: Field Data, 2017.

\section{Conclusion And Recommendations}

Despite the earlier thinking that farmers usually divert most of the loan provided for farming activities into non-farming ventures, the findings of this study have shown the reverse as cooperative farmers in Ohaukwu LGA of Ebonyi State repaid about $78 \%$ of their borrowed loan. Thus, it was concluded that there exist high significant difference between the amount of loan obtained and the amount repaid by cooperative farmers in Ohaukwu LGA of Ebonyi State, Nigeria. 
Based on the findings, the study recommended that financial institutions should address the issue of inadequate credit extended to cooperative farmers by increasing credit supply to them as such will help to improve their productivity and income generation; and that regular training and retraining programme should be provided for the cooperative farmers to keep them abreast of best practices in cooperative management.

\section{References}

[1]. Abdu, Z., Mohammed, S. and Sambo, A. S. (2015). Socioeconomic Determinants of Loan Repayment among the Agricultural Loan Scheme beneficiaries in Kaduna State: A Case Study of Unity Bank PLC. IOSR Journal of Economics and Finance (IOSR-JEF), 6(4): 63-67.

[2]. Acquah, H.D. and Addo, J. (2011). Determinants of Loan Repayment Performance of Fishermen: Empirical Evidence from Ghana. Cercetări Agronomice în Moldova, XLIV(4/148): 89-97.

[3]. Adebayo, O. O. and Adeola. R. G. (2008). Sources and uses of agricultural credit by small scale farmers in Surulere Local Government Area of Oyo State. Anthropologist, 10 (4): 313-324.

[4]. Adedayo, A. and Yusuf, O.R. (2004). Cooperatives and Poverty Alleviation in Rural Settlements of Kwara State, Nigeria. Savanna, 19(2): 123-131.

[5]. Adefila, J. O. (2012). Spatial assessment of farmers' cooperatives organizations in agricultural development in Gurara area of Niger State, Nigeria. Journal of Ecology and Natural Environment, 4(2): 51-57.

[6]. Afolabi JA (2010). Analysis of Loan Repayment among Small Scale Farmers in Oyo State, Nigeria. Journal of Social Sciences, 22(2): 115-119.

[7]. Akinwumi, J. (2006). Road map to re-engineering cooperatives in Nigeria. A paper presented at the south west cooperative leaders conference, organized by cooperative federation of Nigeria South west zone at Obisesan Hall, Ibadan, September 7.

[8]. Anigbogu, T.U., Onugu, C.U., Onyeugbo, B.N. and Okoli, M.I. (2014). Determinants of loan repayment among cooperative farmers in Awka North L.G.A of Anambra State, Nigeria. European Scientific Journal, 10(22): 168-190.

[9]. Arene, C.J. (1992). Loan repayment and technical assistance among smallholder maize farmers in Nigeria. African Review of Money and Banking. A Suppl. Savings and Development Journal, 1: 64-72.

[10]. Awoke, M.U. (2004). Factors affecting loan Acquisition and Repayment pattern of small holder farmers in Ika North East of Delta State Nigeria. Journal of Sustainable Tropical Agricultural Research, 9: 61-64.

[11]. Awunyo-Vitor, D. (2012). Determinants of loan repayment default among farmers in Ghana. Journal of Development and Agricultural Economics, 4(13): 339-345

[12]. Bhuyan, S. (2007). The "people" factor in cooperatives: An analysis of members' attitudes and behaviour. Canadian Journal of Agricultural Economics/Revue canadienned'agroeconmoie, 55(3):275-298.

[13]. Bibby, A. and Shaw, L. (2005). Making a difference: Cooperative solution to Global poverty. Manchester, UK: Cooperative College for the Department of International Development.

[14]. Epetimehin, F. M. (2006). Understanding the Dynamics of Cooperatives. Ibadan: Tadon Publishers.

[15]. Ezeh, A.N. (2013). Extension agents' access and utilization of information and communication technology (ICT) in extension service delivery in South East Nigeria. Journal of Agricultural Extension and Rural Development, 5(11): 266-276.

[16]. International Cooperative Alliance (ICA) (1995). International Co-operatives Research Conference, Statement on the Cooperative Identity. Geneva.

[17]. Kohansal, M.R. and Mansoori, H. (2009). Factors affecting on loan repayment performance of farmers in Kharasan-Razavi province of Iran. A paper presented in a conference on International Research on Food Security. Natural Resource Management and Rural Development, University of Hamburg, October 6-8.

[18]. National Population Commission (NPC) (2006). Bulletin, Federal Ministry of Information, Abuja.2 (7): 11-20.

[19]. Nwachukwu, I.N., Alamba, C.S. and Oko-Isu, A. (2010). Determinants of institutional credit repayment performance among farmers in Afikpo North LGA of Ebonyi state, Nigeria. Advances in Agriculture \& Botanics- International Journal of the Bioflux Society, 2(3): 279-284

[20]. Nwibo, S.U. and Okorie, A. (2013). Constraints to Entrepreneurship and Investment Decisions Among Agribusiness Investors in Southeast, Nigeria. International Journal of Small Business and Entrepreneurship Research, 1(4): 38-50.

[21]. Nwibo, S. U., Mbam, B. N., and Biam, C. K. (2016). Determinants of Agripreneurship among the Rural Households of Ishielu Local Government Area of Ebonyi State. Journal of Biology, Agriculture and Healthcare, 6(13): 3-10.

[22]. Oboh, V.U. and Ekpebu, I.D. (2011). Determinants of formal agricultural credit allocation to the farm sector by arable crop farmers in Benue State, Nigeria. African Journal of Agricultural Research, 6(1): 181-185.

[23]. Ofuoku, A.U. and Urang, E. (2009). Effect of cohesion on loan repayment in farmers' cooperative societies in Delta State Nigeria. International Journal of Sociology and Anthropology, 1(4), 070-076.

[24]. Ojiako, I. A. and Ogbukwa B. C. (2012). Economic analysis of loan repayment capacity of small-holder cooperative farmers in Yewa North Local Government Area of Ogun State, Nigeria. African Journal of Agricultural Research, 7(13): 2051-2062.

[25]. Oladeebo, J.O. and Oladeebo O.E. (2008). Determinants of loan repayment among smallholder farmers in Ogbomoso agricultural zone of Oyo State, Nigeria. Journal of Soc. Science, 17(1): 59-62.

[26]. Olagunju, F.I. and Adeyemo, R. (2007). Determinants of repayment Decision among Small Holder Farmers in Southwestern Nigeria. Pakistan J. Soc. Sci., 4(5): 677-686.

[27]. Poulton, C., Kydd, J. and Dorward, A. (2006). Overcoming market constraints on pro-poor agricultural growth in sub-sharan Africa. Development Policy Review, 24(3): 243-277.

[28]. Udoh, E.J. (2008). Estimation of loan default among beneficiaries of a state government owned agricultural loan scheme, Nigeria. Journal of Central European Agriculture, 9(2): 343-352.

[29]. Ugbomeh, G. M. M., Achoja, F. O., Ideh, V. and Ofuoku, A.U. (2008). Determinants of Loan Repayment Performance Among Women Self Help Groups in Bayelsa State, Nigeria. Agriculturae Conspectus Scientificus, 73(3): 189-195.

[30]. Veerakumaran, S. (2005). Role of cooperatives in food security: A case study of Ethiopia. Department of cooperative. Faculty of Dryland Agriculture and Natural Resources, Makeke University.

[31]. Vosanka I. P., Alam, M. K., Simon, B.P. and Rikwentishe, R. (2015). Analysis of saving pattern of co-operative farmers in Sardauna Local Government Area of Taraba State, Nigeria. ARPN Journal of Science and Technology, 5(1): 10-16.

[32]. Yamusa, I. and Adefila, J. O. (2014). Farmers' Cooperatives and Agricultural Development in Kwali Area Council Federal Capital Territory Abuja, Nigeria. International Journal of Humanities and Social Science, 4(7-1): 161-169. 